\title{
A systematic literature review of the effect of different prosthetic components on human functioning with a lower-limb prosthesis
}

\author{
Harmen van der Linde, MD, PhD; Cheriel J. Hofstad, MsC; Alexander C. H. Geurts, MD, PhD; \\ Klaas Postema, MD, PhD; Jan H. B. Geertzen, MD, PhD; Jacques van Limbeek, MD, PhD \\ Rehabilitation Center Sint Maartenskliniek, Nijmegen, The Netherlands; Center for Rehabilitation, University Hospital \\ Groningen, The Netherlands
}

\begin{abstract}
A correct prosthetic prescription can be derived from adapting the functional benefits of a prosthesis to the functional needs of the prosthetic user. For adequate matching, the functional abilities of the amputees are of value, as well as the technical and functional aspects of the various prosthetic components. No clear clinical consensus seems to be given on the precise prescription criteria. To obtain information about different prosthetic components and daily functioning of amputees with a prosthesis, we performed a systematic literature search. The quality of the studies was assessed with the use of predetermined methodological criteria. Out of 356 potentially relevant studies, 40 studies eventually qualified for final methodological analysis and review. Four satisfied all the criteria and were classified as A-level studies, 26 as B-level, and 10 studies as C-level studies. Despite a huge amount of literature, our formal clinical knowledge had considerable gaps concerning the effects of different prosthetic components and their mechanical characteristics on human functioning with a lowerlimb prosthesis. Therefore, with regard to prosthetic guideline development, we must still largely rely on clinical consensus among experts. The integration of knowledge from research with the expert opinion of clinical professionals and the opinions and wishes of consumers can form a solid base for a procedure on guideline development for prosthetic prescription.
\end{abstract}

Key words: artificial limbs, biomechanical parameters, human functioning, lower-limb amputation, physiological parameters, prosthesis, prosthetic foot, prosthetic knee, prosthetic prescription, prosthetic suspension, socket, stump, systematic review.

\section{INTRODUCTION}

Prosthetic prescription for patients with lower-limb amputation is primarily based on empirical knowledge. Many options are available for different prosthetic components; however, prescription criteria are based mainly on subjective experiences of physicians, therapists, and prosthetists $[1,2]$. On the other hand, third-party payers frequently require justification for purchasing costly prostheses [2]. Also, clarity for the customer is required since quality of care is becoming more important. In the ideal situation, prosthetic prescription is based on adjusting the mechanical characteristics of a prosthesis to the functional needs of the prosthetic user [3], yet no clinical guidelines seem to be available for this use.

The development of scientifically based clinical guidelines is a way of making health care more consistent and efficient and diminishes the gap between what clinicians do and what scientific evidence supports. A systematic

\footnotetext{
Abbreviations: $\mathrm{CVZ}=$ Dutch Health Care Insurance Board, EMG = electromyographic, $\mathrm{RCT}=$ randomized controlled trial, ROM = range of motion, SACH = Solid Ankle Cushion Heel.

This material was based on work supported by the Dutch Health Care Insurance Board (CVZ).

Address all correspondence to $\mathrm{H}$. van der Linde, Rehabilitation Center Sint Maartenskliniek, P.O. Box 9011, 6500 GM Nijmegen, The Netherlands; +31-24-365-9420; fax: +31-24-3659618; email: h.vanderlinde@SMK-research.nl.
} 
literature review is the first step in clinical guideline development. It may also highlight knowledge gaps in the existing evidence [4]. To our knowledge, no scientifically based guidelines for lower-limb prosthetic prescription exist. Also, no consensus seems to exist among different professionals with regard to the criteria for selecting prosthetic components related to the functional abilities and needs of patients. In this perspective, the Dutch Health Care Insurance Board (CVZ) has initiated a national project to develop clinical guidelines for lowerlimb prosthetic prescription to obtain consensus among clinicians, manufacturers, and insurance companies in the Netherlands. The first step is to extract as much scientifically based knowledge from the literature as possible. In this respect, two types of studies can be distinguished: (1) clinical studies focusing on motor performance or daily functioning with a lower-limb prosthesis and (2) technical studies focusing on the mechanical characteristics of prosthetic components without specifically human functioning. In view of prosthetic guideline development, only studies addressing motor performance and human functioning with a lower-limb prosthesis are considered relevant. Hence, this review will be restricted to these clinically oriented studies.

\section{METHOD}

\section{Procedure}

We performed a systematic search using the Medline database (from 1966), Current Contents (from 1996), The Cochrane Database (2001 issue), and Psyclit (from 1971) until February 2001. A combination of the following key words and their synonyms was used: lower-limb prosthesis, lower-limb amputation, prosthetic prescription, prosthetic foot, prosthetic knee, prosthetic suspension, stump, socket, and physiological and biomechanical parameters. Also we checked the references from the retrieved articles and (systematic) reviews to extend the search.

Based on their abstracts, studies were further considered when:

1. The papers were written in the English, German, or Dutch languages.

2. The study design was either a randomized controlled trial (RCT), a cohort study, or a case-controlled study, allowing at least some control of confounding factors.
3. The study investigated patients with a transfemoral, through-knee, or transtibial amputation.

4. The study used subjective findings, activities of daily living measures, and/or functional characteristics of human stance or gait (spatio-temporal, physiological, kinematic, kinetic, or electromyographic [EMG] parameters) as outcome variables.

5. The study evaluated specific components of the prosthesis.

6. The goal of the study was to provide insight into the effects of different prosthetic components on human functioning with a lower-limb prosthesis.

\section{Methodological Criteria}

After this abstract-based selection of relevant studies, we assessed the methodological quality of each article using a checklist of 13 predetermined criteria. This checklist was based on the integration of two existing criteria lists for quality assessment [5,6], which were originally developed to evaluate randomized controlled trials (see Appendix, which can be found in the online version only $[7,8]$ ). Some criteria were adapted for nonrandomized controlled trials. Each criterion was scored at two levels: invalid/no "0" and valid/yes "1." If a criterion was not applicable, it was scored " 0 ." Two reviewers (HL and $\mathrm{CH}$ ) independently analyzed the studies. If the reviewers found a discrepancy, they achieved consensus in the second instance.

For this review, the included studies were required to sufficiently control for selection and measurement bias. Studies were classified as-

- A-level studies: Studies with a total score of at least 11 points or more, including 6 points out of the A- and Bcriteria, including a positive score for blinded outcome assessment (criterion B7) and timing of the measurement (criterion B8).

- B-level studies: Studies with a total score between 6 and 10 points, including a positive score for timing of the measurement (criterion B8).

- C-level studies: Studies with a total score of at least 6 points out of the A- and B-criteria with an invalid score on criteria B7 and B8.

Therefore, only the studies in which the total score of the A- and B-criteria was at least 6 out of a possible 9 points were used in the best-evidence synthesis. 


\section{RESULTS}

\section{Selection of Studies}

Out of 356 potentially relevant studies on lower-limb prosthetic functioning, we selected 64 studies based on their abstracts (see the Figure for the selection algorithm according to the QUOROM statement [9]). References from the retrieved studies and (systematic) reviews yielded 72 more papers. We similarly assessed the abstracts of these 72 studies, selecting 17 additional studies and fulfilling the preliminary selection criteria. Most of the studies that did not meet these criteria were either uncontrolled case series or case reports (criterion A1) or their primary purpose was not related to human functioning with a prosthesis (criterion B6). For instance, many articles focused only on amputation techniques or on the technical possibilities of early prosthetic fitting. Hence, we methodologically assessed the full texts of 81 selected studies using the checklist of 13 criteria just mentioned [1-3,10-87]. Based on these assessments, 40 studies received an A-, B- or C-level classification and were included for final review (Tables 1 and 2). An important reason for excluding the 41 other studies was that the selection of the study sample was so poorly described that the results could not be reliably interpreted from a clinical perspective.

No classical RCTs were identified, yet all included studies used crossover designs that allowed sufficient control for confounding. Four papers were classified "A-level studies” $[17,18,67,68]$, twenty-six "B-level studies” [2,3, 13,16,20,22,23,27,30,36,37,42,44-46,55-58,61,66,69,71, $77,81,83]$, whereas ten studies were classified "C-level studies” [1,15,35,39,52-54,59,63,76]. The main difference between the A- and B-level studies was a negative score on the "blinded assessment" (criterion B7). Indeed, only Postema et al. [67,68], Boonstra et al. [17,18], and Gailey et al. [35] (C-level study) reported that their subjects were blinded to the intervention. Seven studies applied no randomization of the sequence of interventions [2,20,42,46, $52,61,71]$ and, therefore, had a negative score on criterion A4. Of the other studies, only Postema et al. described which randomization procedure was applied $[67,68]$. The randomization was done with the aid of a dice, and the code was broken only after the entire trial had been completed. Seven articles scored negatively for functional homogeneity [16-18,22,23,30,81]. Based on the provided subject characteristics, the study sample could be concluded to be considerably heterogeneous for activity level, which was not accounted for by a stratified analysis.

In some studies, the prosthetic components, other than the component investigated, were not kept constant, resulting in a " 0 " on criterion B6 [1,15,39,44,55,56,61,63,76]. In eight studies on prosthetic mass [35,39,52-54,59,63,76] and the Board's study on prosthetic socket design [15], the subjects were not allowed sufficient time to adapt to the intervention, so they received a negative B8 score. Eight studies did not indicate possible dropouts [1,3,16,30,52, $53,76,81]$. Insufficient information was available about how many subjects were eventually subjected to the intervention. Therefore, this study received a negative score on criterion C10. In six studies, the authors failed to provide adequate measures of variability, even though such data were necessary to interpret the results $[1,13,15,63,71,81]$.

\section{Selected Study Results}

The selected studies on functioning with a lower-limb prosthesis allowed a division in four categories based on their focus of attention: effects of different (1) prosthetic feet, (2) prosthetic knees, (3) prosthetic sockets, and (4) prosthetic mass. The prosthetic foot was the focus of investigation in 28 studies [1-3,13,16,20,22,23,30,36,44, 45,52,53,55-58,63,66-69,71,76,77,81,83]. The main clinical findings are shown in Table 3 . The prosthetic knee was the focus in five studies $[17,18,42,46,61]$, the prosthetic socket in one study [15], and prosthetic mass in six studies [25,35,37,39,54,59], with the main clinical findings in Table 4.

As dependent variables, time-distance parameters are probably the most easily obtainable objective data for evaluating changes in a patient's gait performance [88]. From a clinical point of view, such parameters are also readily interpretable. Hence, many of the included studies focused primarily on these parameters as well as on kinematic variables $[1-3,13,15,16,22,30,36,37,39,45,52$, $53,56,57,59,61,63,66-68,71,76,77,81,83]$. Fifteen studies used oxygen uptake $[13,17,20,25,35,44,45,52,54,58,59$, $63,76,81,83]$, and two studies assessed heart rate $[46,63]$. To evaluate the difficulty of walking, 1 study used the Borg scale [56], 2 studies evaluated patient satisfaction [20,67], and 21 studies used walking speed to investigate differences between specific prosthetic components $[1,2,13,16,20,22,25,39,46,52-54,61,63,66,68,69,71,76$, $77,81]$. 


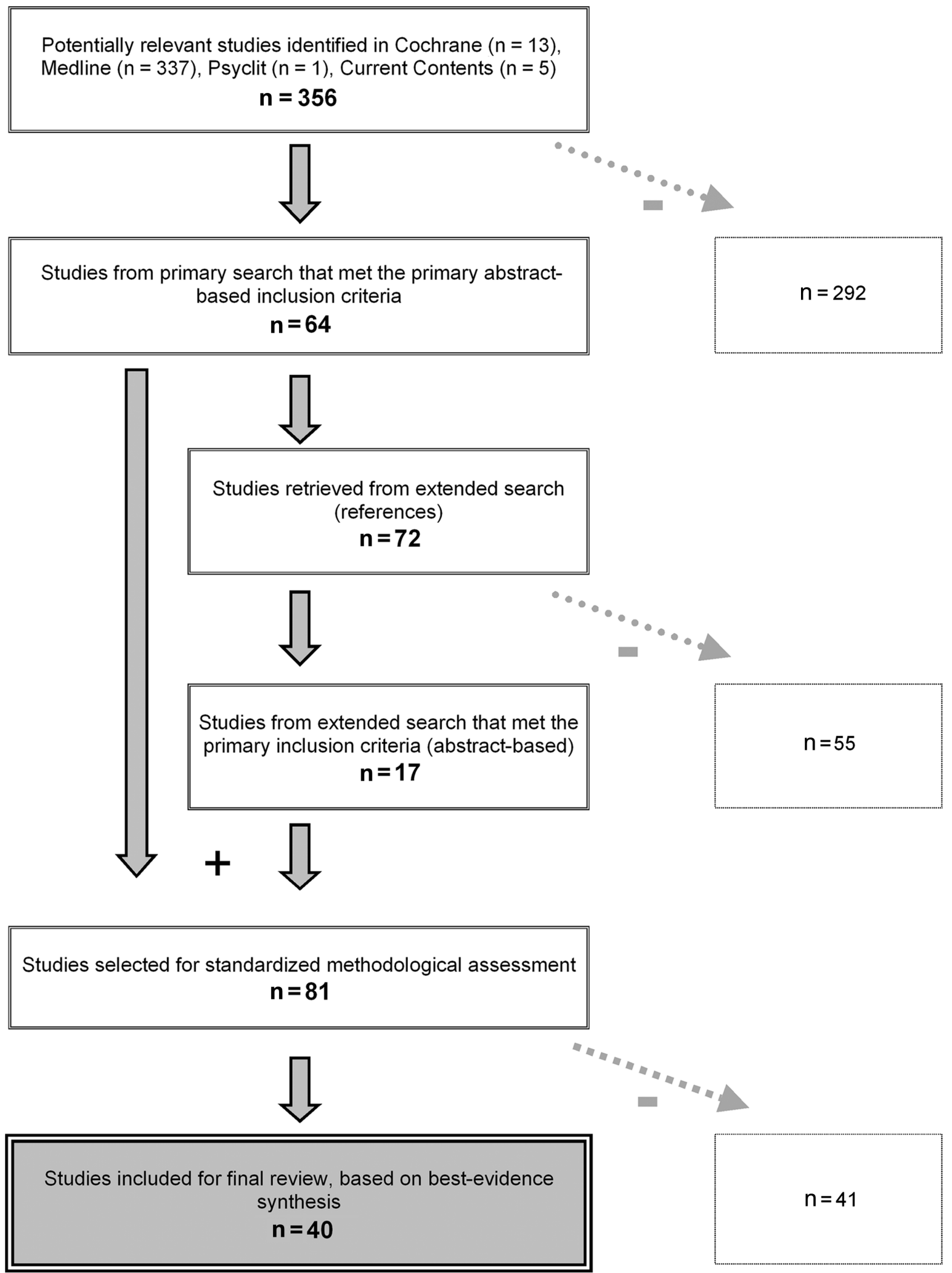

Figure.

Selection algorithm. 
Table 1.

Assessment of methodological aspects of reviewed studies on prosthetic feet.

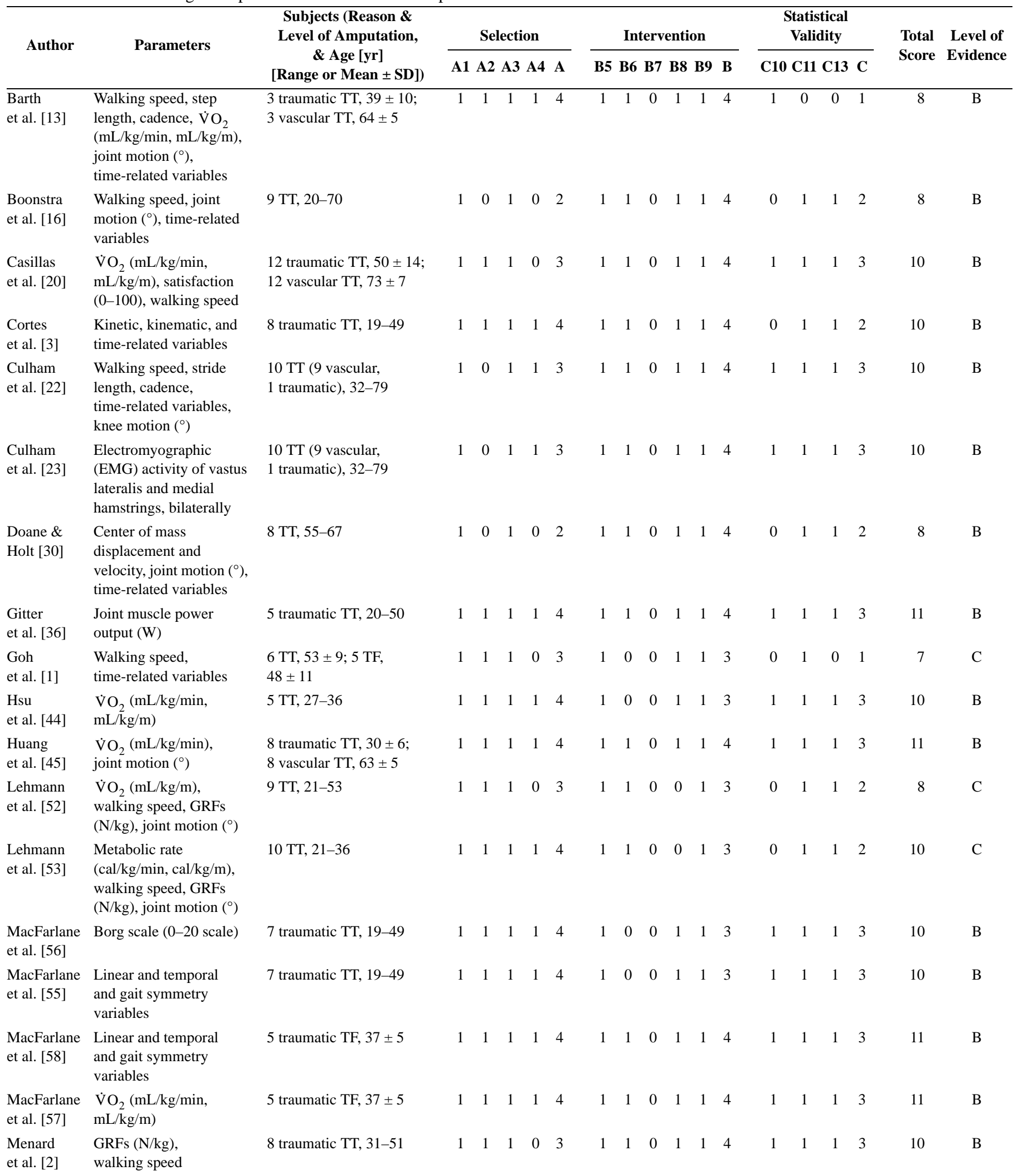


JRRD, Volume 41, Number 4, 2004

Table 1. (Continued)

Assessment of methodological aspects of reviewed studies on prosthetic feet.

\begin{tabular}{|c|c|c|c|c|c|c|c|c|c|c|c|c|c|c|c|c|c|c|c|}
\hline \multirow{3}{*}{ Author } & \multirow{3}{*}{\multicolumn{2}{|c|}{$\begin{array}{c}\text { Subjects (Reason \& } \\
\text { Level of Amputation, } \\
\text { \& Age [yr] } \\
\text { [Range or Mean } \pm \text { SD]) }\end{array}$}} & \multirow{2}{*}{\multicolumn{5}{|c|}{ Selection }} & \multicolumn{12}{|c|}{ Statistical } \\
\hline & & & & & & & & \multicolumn{6}{|c|}{ Intervention } & \multicolumn{4}{|c|}{ Validity } & \multirow{2}{*}{$\begin{array}{l}\text { Total } \\
\text { Score }\end{array}$} & \multirow{2}{*}{$\begin{array}{l}\text { Level of } \\
\text { Evidence }\end{array}$} \\
\hline & & & A1 & A2 & A3 & A4 & $\mathbf{A}$ & B5 & B6 & B7 & B8 & B9 & $\mathbf{B}$ & C10 & C11 & C13 & C & & \\
\hline $\begin{array}{l}\text { Nielsen } \\
\text { et al. [63] }\end{array}$ & $\begin{array}{l}\text { Walking speed, } \dot{\mathrm{VO}_{2}} \\
(\mathrm{~mL} / \mathrm{kg} / \mathrm{min}, \mathrm{mL} / \mathrm{kg} / \mathrm{m}) \text {, } \\
\text { heart rate }\end{array}$ & 7 traumatic TT, $27 \pm 7$ & 1 & 1 & 1 & 1 & 4 & 1 & 0 & 0 & 0 & 1 & 2 & 1 & 0 & 0 & 1 & 7 & $\mathrm{C}$ \\
\hline $\begin{array}{l}\text { Perry } \\
\text { et al. [66] }\end{array}$ & $\begin{array}{l}\text { Walking speed, cadence, } \\
\text { joint motion }\left(^{\circ}\right) \text {, and } \\
\text { velocities (rad/s) }\end{array}$ & 10 vascular TT, 49-72 & 1 & 1 & 1 & 1 & 4 & 1 & 1 & 0 & 1 & 1 & 4 & 1 & 1 & 1 & 3 & 11 & B \\
\hline $\begin{array}{l}\text { Postema } \\
\text { et al. [67] }\end{array}$ & Preference (0-10 scale) & $\begin{array}{l}10 \text { traumatic/oncologic } \\
\mathrm{TT}, 34-66\end{array}$ & 1 & 1 & 1 & 1 & 4 & 1 & 1 & 1 & 1 & 1 & 5 & 1 & 1 & 1 & 3 & 12 & A \\
\hline $\begin{array}{l}\text { Postema } \\
\text { et al. [68] }\end{array}$ & $\begin{array}{l}\text { Walking speed, cadence, } \\
\text { joint motion, GRFs, } \\
\text { energy absorption }\end{array}$ & $\begin{array}{l}10 \text { traumatic/oncologic } \\
\text { TT, 34-66 }\end{array}$ & 1 & 1 & 1 & 1 & 4 & 1 & 1 & 1 & 1 & 1 & 5 & 1 & 1 & 1 & 3 & 12 & A \\
\hline $\begin{array}{l}\text { Powers } \\
\text { et al. [69] }\end{array}$ & $\begin{array}{l}\text { Walking speed, stride } \\
\text { length, cadence, GRFs } \\
\text { (\% body weight), ankle } \\
\text { motion }\left(^{\circ}\right)\end{array}$ & 10 traumatic TT, 22-72 & 1 & 1 & 1 & 1 & 4 & 1 & 1 & 0 & 1 & 1 & 4 & 1 & 1 & 1 & 3 & 11 & B \\
\hline $\begin{array}{l}\text { Rao } \\
\text { et al. [71] }\end{array}$ & $\begin{array}{l}\text { Walking speed; stride } \\
\text { length (m); cadence, } \\
\text { foot, shank, and thigh } \\
\text { velocities (rad/s) }\end{array}$ & 9 vascular TT, $62 \pm 7$ & 1 & 1 & 1 & 0 & 3 & 1 & 1 & 0 & 1 & 1 & 4 & 1 & 1 & 0 & 2 & 9 & B \\
\hline $\begin{array}{l}\text { Schmalz } \\
\text { et al. [76] }\end{array}$ & $\begin{array}{l}\text { Walking speed, } \\
\text { stride length, } \dot{\mathrm{V}} \mathrm{O}_{2} \\
(\mathrm{~mL} / \mathrm{kg} / \mathrm{m})\end{array}$ & 8 traumatic TT, $17-70$ & 1 & 1 & 1 & 1 & 4 & 1 & 0 & 0 & 0 & 1 & 2 & 0 & 1 & 1 & 2 & 8 & $\mathrm{C}$ \\
\hline $\begin{array}{l}\text { Snyder } \\
\text { et al. [77] }\end{array}$ & $\begin{array}{l}\text { Walking speed, } \\
\text { stride length, cadence, } \\
\text { GRFs (N/kg), } \\
\text { ankle and knee } \\
\text { motion }\left(^{\circ}\right)\end{array}$ & 7 vascular TT, $45-70$ & 1 & 1 & 1 & 1 & 4 & 1 & 1 & 0 & 1 & 1 & 4 & 1 & 1 & 1 & 3 & 11 & B \\
\hline $\begin{array}{l}\text { Torburn } \\
\text { et al. [81] }\end{array}$ & $\begin{array}{l}\text { Walking speed, } \\
\text { cadence, stride length, } \\
\text { EMG, } \dot{\mathrm{V} O} \mathrm{O}_{2} \\
(\mathrm{~mL} / \mathrm{kg} / \mathrm{min}, \mathrm{mL} / \mathrm{kg} / \mathrm{m}) \text {, } \\
\text { joint motion }\left(^{\circ}\right)\end{array}$ & $\begin{array}{l}5 \text { TT (3 traumatic, } \\
2 \text { dysvascular), 43-58 }\end{array}$ & 1 & 0 & 1 & 1 & 3 & 1 & 1 & 0 & 1 & 1 & 4 & 0 & 1 & 0 & 1 & 8 & B \\
\hline $\begin{array}{l}\text { Torburn } \\
\text { et al. [83] }\end{array}$ & $\begin{array}{l}\dot{\mathrm{V}} \mathrm{O}_{2}(\mathrm{~mL} / \mathrm{kg} / \mathrm{min} \text {, } \\
\mathrm{mL} / \mathrm{kg} / \mathrm{m}) \text {, walking } \\
\text { speed, stride length, } \\
\text { cadence }\end{array}$ & $\begin{array}{l}10 \text { traumatic TT, } 51 \pm 6 \text {, } \\
7 \text { vascular TT, } 62 \pm 8\end{array}$ & 1 & 1 & 1 & 1 & 4 & 1 & 1 & 0 & 1 & 1 & 4 & 1 & 1 & 1 & 3 & 11 & B \\
\hline \multicolumn{20}{|c|}{$\begin{array}{l}\text { *See main text "Methods" section for explanation of criteria and symbols and see reference section for references. } \\
\text { Note: Criterion C12 (intention-to-treat) is not mentioned in this table, because this criterion was not applicable in all final-selected studies. } \\
\text { GRF = ground reaction force }\end{array}$} \\
\hline
\end{tabular}

Many different comparisons were made. Furthermore, differences in selected and presented outcome parameters among studies investigating the same prosthetic components did not allow a true meta-analysis of the results. Hence, we decided to focus our review on the consistency of clinical findings across studies on the same topic. In the case of inconsistency, methodological quality was used for final interpretation.

\section{Studies on Prosthetic Feet}

One A-level study [67], fifteen B-level studies $[2,3,13,16,20,22,30,56,57,66,69,71,77,81,83]$, and five C-level studies used time-distance parameters to compare different types of prosthetic feet $[1,52,53,63,76]$. In general, few discriminative effects were found. For instance, in most studies the self-selected (comfortable) walking speed was not influenced by the type of prosthetic foot in 
Table 2.

Assessment of methodological aspects of reviewed studies on prosthetic knee, prosthetic socket, and prosthetic mass.

\begin{tabular}{|c|c|c|c|c|c|c|c|c|c|c|c|c|c|c|c|c|c|c|c|}
\hline \multirow[t]{2}{*}{ Author } & \multirow{2}{*}{ Parameters } & \multirow{2}{*}{$\begin{array}{c}\text { Subjects (Reason \& } \\
\text { Level of Amputation, } \\
\text { \& Age [yr] [Range]) }\end{array}$} & \multicolumn{5}{|c|}{ Selection } & \multicolumn{6}{|c|}{ Intervention } & \multicolumn{4}{|c|}{$\begin{array}{c}\text { Statistical } \\
\text { Validity }\end{array}$} & \multirow{2}{*}{$\begin{array}{l}\text { Total } \\
\text { Score }\end{array}$} & \multirow{2}{*}{$\begin{array}{l}\text { Level of } \\
\text { Evidence }\end{array}$} \\
\hline & & & A1 & A2 & A3 & A4 & A & B5 & B6 & B7 & B8 & B9 & $\mathbf{B}$ & C10 & C11 & C13 & $\mathbf{C}$ & & \\
\hline $\begin{array}{l}\text { Board } \\
\text { et al. [15] }\end{array}$ & $\begin{array}{l}\text { Stump volume (mL), } \\
\text { pistoning (cm), step } \\
\text { length, stance duration }\end{array}$ & 11 traumatic TT, 32-64 & 1 & 1 & 1 & 1 & 4 & 1 & 0 & 0 & 0 & 1 & 2 & 1 & 1 & 0 & 2 & 8 & $\mathrm{C}$ \\
\hline $\begin{array}{l}\text { Boonstra } \\
\text { et al. [17] }\end{array}$ & $\begin{array}{l}\dot{\mathrm{VO}_{2}}(\mathrm{~mL} / \mathrm{kg} / \mathrm{min} \text {, } \\
\mathrm{mL} / \mathrm{kg} / \mathrm{m}) \text {, preference }\end{array}$ & $\begin{array}{l}28 \text { traumatic/oncologic } \\
\text { TF, 15-63 }\end{array}$ & 1 & 0 & 1 & 1 & 3 & 1 & 1 & 1 & 1 & 1 & 5 & 1 & 1 & 1 & 3 & 11 & A \\
\hline $\begin{array}{l}\text { Boonstra } \\
\text { et al. [18] }\end{array}$ & $\begin{array}{l}\text { Walking distance, ease } \\
\text { of walking, temporal } \\
\text { variables, goniometry }\end{array}$ & $\begin{array}{l}28 \text { traumatic/oncologic } \\
\text { TF, 15-63 }\end{array}$ & 1 & 0 & 1 & 1 & 3 & 1 & 1 & 1 & 1 & 1 & 5 & 1 & 1 & 1 & 3 & 11 & A \\
\hline $\begin{array}{l}\text { Czerniecki } \\
\text { et al. [27] }\end{array}$ & $\begin{array}{l}\dot{\mathrm{V}} \mathrm{O}_{2}(\mathrm{~mL} / \mathrm{kg} / \mathrm{m}), \\
\text { walking speed }\end{array}$ & $\begin{array}{l}8 \text { traumatic/oncologic TF, } \\
30-44\end{array}$ & 1 & 1 & 1 & 1 & 4 & 1 & 1 & 0 & 1 & 1 & 4 & 1 & 1 & 1 & 3 & 11 & B \\
\hline $\begin{array}{l}\text { Gailey } \\
\text { et al. 35] }\end{array}$ & $\dot{\mathrm{V}} \mathrm{O}_{2}(\mathrm{~mL} / \mathrm{kg} / \mathrm{min})$ & $\begin{array}{l}10 \text { traumatic/oncologic } \\
\text { TT, 24-52 }\end{array}$ & 1 & 1 & 1 & 1 & 4 & 1 & 1 & 1 & 0 & 1 & 4 & 1 & 1 & 1 & 3 & 11 & $\mathrm{C}$ \\
\hline $\begin{array}{l}\text { Gitter et al. } \\
\text { [37] }\end{array}$ & $\begin{array}{l}\text { Muscle power output } \\
\text { (W), joint power } \\
\text { output (W) }\end{array}$ & $\begin{array}{l}8 \text { traumatic/oncologic TF, } \\
30-44\end{array}$ & 1 & 1 & 1 & 1 & 4 & 1 & 1 & 0 & 1 & 1 & 4 & 1 & 1 & 1 & 3 & 11 & B \\
\hline $\begin{array}{l}\text { Hale } \\
\text { [39] }\end{array}$ & $\begin{array}{l}\text { Walking speed, } \\
\text { joint motion }\end{array}$ & $\begin{array}{l}6 \text { traumatic/oncologic TF, } \\
22-61\end{array}$ & 1 & 1 & 1 & 1 & 4 & 1 & 0 & 0 & 0 & 1 & 2 & 1 & 1 & 1 & 3 & 9 & $\mathrm{C}$ \\
\hline $\begin{array}{l}\text { Heller et al. } \\
\text { [42] }\end{array}$ & $\begin{array}{l}\text { Sway velocities } \\
(\mathrm{mm} / \mathrm{s})\end{array}$ & $\begin{array}{l}10 \text { traumatic/oncologic } \\
\mathrm{TF}, 38\end{array}$ & 1 & 1 & 1 & 0 & 3 & 1 & 1 & 0 & 1 & 1 & 4 & 1 & 1 & 1 & 3 & 10 & B \\
\hline $\begin{array}{l}\text { Isakov et al. } \\
\text { [46] }\end{array}$ & $\begin{array}{l}\text { Heart rate, walking } \\
\text { speed }\end{array}$ & 14 vascular TF, 50-75 & 1 & 1 & 1 & 0 & 3 & 1 & 1 & 0 & 1 & 1 & 4 & 1 & 1 & 1 & 3 & 10 & B \\
\hline $\begin{array}{l}\text { Lehmann } \\
\text { et al. [54] }\end{array}$ & $\begin{array}{l}\text { Self-selected walking } \\
\text { speed, } \dot{\mathrm{V}} \mathrm{O}_{2}(\mathrm{~mL} / \mathrm{kg} / \mathrm{m})\end{array}$ & $15 \mathrm{TT}, 18-70$ & 1 & 1 & 1 & 1 & 4 & 1 & 1 & 0 & 0 & 0 & 2 & 1 & 1 & 1 & 3 & 9 & $\mathrm{C}$ \\
\hline $\begin{array}{l}\text { Mattes } \\
\text { et al. [59] }\end{array}$ & $\begin{array}{l}\dot{\mathrm{V}} \mathrm{O}_{2}(\mathrm{~J} / \mathrm{s}) \text {, step length, } \\
\text { swing time, stance time }\end{array}$ & $\begin{array}{l}6 \text { traumatic/oncologic TF, } \\
18-50\end{array}$ & 1 & 1 & 1 & 1 & 4 & 1 & 1 & 0 & 0 & 1 & 3 & 1 & 1 & 1 & 3 & 10 & $\mathrm{C}$ \\
\hline $\begin{array}{l}\text { Murray } \\
\text { et al. [61] }\end{array}$ & $\begin{array}{l}\text { Walking speed, stride } \\
\text { length, cadence, tempo- } \\
\text { ral components of gait }\end{array}$ & 7 traumatic TF, 33-46 & 1 & 1 & 1 & 0 & 3 & 1 & 0 & 0 & 1 & 1 & 3 & 1 & 1 & 1 & 3 & 9 & B \\
\hline $\begin{array}{l}\text { *See main te } \\
\text { Note: Criteri } \\
\text { GRF = groun } \\
\mathrm{TT}=\text { transtib } \\
\mathrm{TF}=\text { transfer } \\
\dot{\mathrm{V}} \mathrm{O}_{2}=\text { oxyg }\end{array}$ & $\begin{array}{l}\text { xt "Methods" section for e } \\
\text { on C12 (intention-to-treat) } \\
\text { d reaction force } \\
\text { ial } \\
\text { noral } \\
\text { en uptake }\end{array}$ & $\begin{array}{l}\text { anation of criteria and syn } \\
\text { ot mentioned in this table }\end{array}$ & & & & ic & & 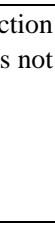 & & & & & & ele & & & & & \\
\hline
\end{tabular}

traumatic $[2,3,13,56,67,76,81,83]$ or vascular transtibial amputees [13,22,66,71,81,83], and traumatic transfemoral amputees [57]. A few exceptions, however, were found. Compared to the SACH (Solid Ankle Cushion Heel) foot, three B-level studies found a higher selfselected walking speed with a prototype energy-storing foot in traumatic transtibial amputees [20] and with the Flex-Foot in traumatic [69] and vascular transtibial amputees [77]. Casillas et al. explained their results by the higher bioenergetic efficiency level the subjects experienced while walking with the prototype energy-storing foot [20]. Powers et al. and Snyder et al. both explained the observed difference in walking speed by the greater stride length with the Flex-Foot compared to the SACH foot $[69,77]$, while cadence remained constant. Two studies reported a change in cadence. MacFarlane et al. found a lower cadence when individuals walked with the FlexFoot compared to the SACH foot in combination with a greater stride length for the Flex-Foot [56]. Because of a trade-off effect, no differences were found in walking speed. Torburn et al. found a greater cadence for the Carbon Copy II foot compared with the Flex-Foot and SACH foot [81]. A possible explanation for the slightly different study results may be found in the differences in 
JRRD, Volume 41, Number 4, 2004

Table 3.

Main clinical findings of reviewed studies on prosthetic feet. ${ }^{*}$

\begin{tabular}{ll}
\hline \multicolumn{1}{c}{ Author } & \multicolumn{1}{c}{ Intervention } \\
\hline $\begin{array}{l}\text { Barth et al. } \\
\text { [13] }\end{array}$ & $\begin{array}{l}\text { SACH foot, SAFE II, } \\
\text { Seattle Lightfoot, Quantum, } \\
\text { Carbon Copy II, Flex-Walk }\end{array}$ \\
& \\
$\begin{array}{l}\text { Boonstra et al. } \\
\text { [16] }\end{array}$ & Multiflex, Quantum \\
& \\
Casillas et al. & \\
[20] & SACH foot, energy-storing \\
& foot (prototype) \\
Cortes et al. & SACH foot, Single Axis, \\
[3] & Greissinger, Dynamic foot \\
Culham et al. & SACH foot, Single Axis \\
[22] &
\end{tabular}

Culham et al. SACH foot, Single Axis [23]$$
\text { foot, Single Axis }
$$

Traumatic amputees: significantly shorter sound limb when wearing Flex-Walk and SAFE

Level of

Evidence

II; however, when wearing SACH, they had significantly longer sound-limb step length.

Total group: with SACH foot, they had less dorsiflexion; with Flex-Walk, greater dorsiflexion than sound limb; with wearing Carbon Copy II and Quantum, greater sound limb acceptance forces. No significant differences in energy cost among prosthetic feet.

No differences in walking speed, plantar-dorsiflexion range of motion (ROM), knee joint ROM, hip flexion-extension ROM. Quantum foot: longer swing phase on prosthetic side, step time longer, inversion-eversion angle was $2.1^{\circ}$ larger, adduction-abduction ROM was $3.1^{\circ}$ larger.

For traumatic amputees with energy-storing foot: free walking speed was higher, $\dot{\mathrm{V}} \mathrm{O}_{2}$ (per meter) was lower, more significant as speed increased. Higher satisfaction rating when amputees walked with energy-storing foot. No differences found for vascular patients.

Similar behavior for SACH and Dynamic feet (nonarticulated mechanism) on one hand and for Single Axis and Greissinger (articulated mechanism) on other hand.

No differences in walking speed, cadence, stride length, gait cycle duration, mean peak stance phase flexion of prosthetic and contralateral limb. Angle of peak swing flexion was $46.37^{\circ} \pm 9.60^{\circ}$ with SACH and differed significantly from Single Axis $\left(41.34^{\circ} \pm\right.$ $7.44^{\circ}$ ) in prosthetic limb; for contralateral limb, following angles were found: $51.35^{\circ} \pm$ $4.12^{\circ}$ and $47.71^{\circ} \pm 7.10^{\circ}$.

No differences of activity patterns of quadriceps in sound limb. SACH foot: peak quadriceps activity occurred later (30\%) in stance phase of prosthetic limb than Single Axis foot (30\%). SACH foot: hamstrings of prosthetic limb were active throughout early- and midstance phase, and peak activity occurred at 30\% of gait cycle; with Single Axis foot, two peaks of hamstrings activity were observed (at 10\% and 60\%).

$\begin{array}{ll}\begin{array}{l}\text { Doane and Holt } \\ \text { [30] }\end{array} & \text { SACH foot, Single Axis } \\ \begin{array}{l}\text { Gitter et al. } \\ \text { [36] }\end{array} & \text { SACH foot, Seattle Foot, } \\ \text { Goh et al. } & \text { Flex-Foot } \\ {[1]} & \text { SACH foot, uniaxial foot }\end{array}$

No differences in velocity of center of mass. SACH foot: ankle angle of prosthetic leg during foot-flat was less than with Single Axis foot $\left(-5.4 \pm 2.1^{\circ}\right.$ and $-11.9 \pm 3.0^{\circ}$, respectively).

Seattle and Flex-Foot: increase in energy absorption and release during push-off, but no differences in pattern or magnitude of knee and hip power outputs compared to SACH foot.

No differences in walking speed. SACH foot: period of heel-strike to foot-flat of prosthetic leg took twice as long as that of uniaxial foot for transtibial and transfemoral amputees (44.5\% vs. $22.4 \%$ and $33.7 \%$ vs. $20.4 \%$, respectively). Transtibial and transfemoral showed an average difference of $7.5^{\circ}$ and $5.0^{\circ}$, respectively, in ankle angle during early-stance phase. No differences in GRFs for transtibial amputees. Vertical GRF on prosthetic side for transfemoral amputees showed differences in its loading pattern: SACH foot has two-peak loading pattern, uniaxial a three-peak loading pattern.

$\begin{array}{ll}\begin{array}{l}\text { Hsu et al. } \\ {[44]}\end{array} & \begin{array}{l}\text { SACH foot, Flex-Foot, } \\ \text { Re-Flex VSP }\end{array} \\ \begin{array}{l}\text { Huang et al. } \\ {[45]}\end{array} & \begin{array}{l}\text { SACH foot, Single Axis, } \\ \text { Multiple Axis }\end{array} \\ \begin{array}{l}\text { Lehmann et al. } \\ {[52]}\end{array} & \begin{array}{l}\text { SACH foot, Seattle Foot, } \\ \text { Flex-Foot }\end{array} \\ \begin{array}{l}\text { Lehmann et al. } \\ {[53]}\end{array} & \text { SACH foot, Seattle Foot }\end{array}$

Improvements of Re-Flex VSP vs. Flex-Foot and SACH foot: energy cost-walking 5\% and running $11 \%$, gait efficiency-walking $6 \%$ and running $9 \%$. No differences between Flex-Foot and SACH foot.

No differences in energy consumption. SACH foot: good late-stance stability, limited dorsiflexion. Multiple Axis foot: less late-stance stability, more late-stance dorsiflexion. Ankle joint degree of freedom is an important factor for comfort; Multiple Axis most comfortable.

No differences in walking speed, and metabolic efficiency during walking and running. Flex-Foot: longest midstance phase, greatest ankle angle range, and greater forward movement of center of pressure.

No differences in walking speed and in metabolic efficiency during walking and running. Seattle Foot: longer midstance phase, push-off phase was shorter, ankle ROM during stance was greater $\left(20.2^{\circ}\right.$ vs. $\left.9.8^{\circ}\right)$, maximal dorsiflexion moment was greater $(97.5 \mathrm{Nm}$ vs. $84.3 \mathrm{Nm})$, knee ROM during stance was greater $\left(43.2^{\circ}\right.$ vs. $\left.34.3^{\circ}\right)$, knee ROM during swing was greater $\left(66.0^{\circ}\right.$ vs. $\left.62.1^{\circ}\right)$.

MacFarlane et al. Conventional foot, Flex-Foot Walking with conventional foot was more difficult across all grade and speed conditions.

No differences in walking speed. Flex-Foot: stride length increased (134.3 cm compared to $129.8 \mathrm{~cm}$ ) and cadence decreased; single support time increased, allowing larger, more normal steps with uninvolved leg, which means decrease of cadence, reflected by increase in cycle time (124.3 for Flex-Foot and 122.2 for conventional foot). 
Table 3. (Continued)

Main clinical findings of reviewed studies on prosthetic feet.

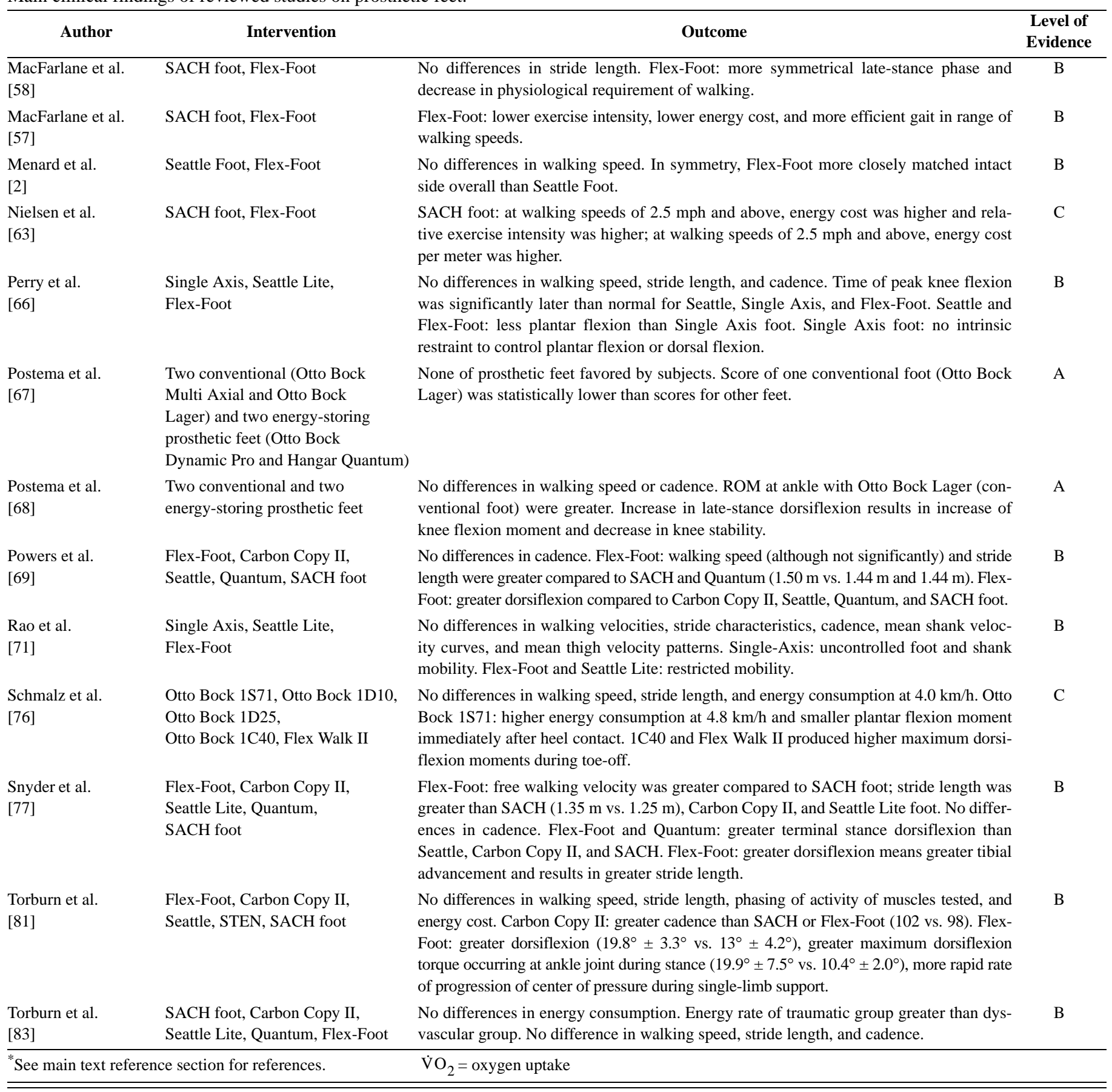

the selection of the study groups. In two B-level studies, MacFarlane et al. reported a more symmetrical gait pattern with the Flex-Foot compared to a SACH foot in both transtibial and transfemoral amputees related to symmetrization of the late stance and late swing phase durations in particular [56,57].
Some studies investigated joint motion as an outcome parameter [13,16,22,45,52,53,66,67,69,77,81]. In the A-level study by Postema et al. [67], the range of motion (ROM) at the ankle during the stance phase of a single-axis conventional foot was greater than the same ROM of two energy-storing feet. This result could readily 
JRRD, Volume 41, Number 4, 2004

Table 4.

Main clinical findings of reviewed studies on prosthetic knee, prosthetic socket, and prosthetic mass.

\begin{tabular}{|c|c|c|c|}
\hline Author & Intervention & Outcome & $\begin{array}{l}\text { Level of } \\
\text { Evidence }\end{array}$ \\
\hline \multicolumn{4}{|l|}{ Knee } \\
\hline $\begin{array}{l}\text { Boonstra } \\
\text { et al. [17] }\end{array}$ & $\begin{array}{l}\text { Mechanical swing phase control } \\
\text { (Otto Bock) and pneumatic swing } \\
\text { phase control (Tehlin knee) }\end{array}$ & $\begin{array}{l}\text { Six patients preferred Otto Bock } 3 \text { R20 because bending Tehlin knee was very easy, } \\
\text { which gave an unsafe feeling; Nineteen patients preferred Tehlin knee because they } \\
\text { walked more easily and/or faster. Walking with Tehlin knee required more energy. }\end{array}$ & A \\
\hline $\begin{array}{l}\text { Boonstra } \\
\text { et al. [18] }\end{array}$ & $\begin{array}{l}\text { Mechanical swing phase control } \\
\text { (Otto Bock) and pneumatic swing } \\
\text { phase control (Tehlin knee) }\end{array}$ & $\begin{array}{l}\text { Normal speed: walk faster and more comfortably with Tehlin knee. Fast walking is easier } \\
\text { with Tehlin knee. Tehlin knee: duration of swing phase of prosthetic side is greater, stride } \\
\text { time is greater, hip range of motion (ROM) is not different, knee ROM is smaller, and } 10^{\circ} \\
\text { flexion duration is shorter. }\end{array}$ & A \\
\hline $\begin{array}{l}\text { Heller } \\
\text { et al. [42] }\end{array}$ & $\begin{array}{l}\text { Conventional knee unit vs. } \\
\text { Intelligent Prosthesis knee unit }\end{array}$ & $\begin{array}{l}\text { Gait using Intelligent Prosthesis was not less cognitively demanding then using conven- } \\
\text { tional knee mechanism. Total sway during gait was significantly less for Intelligent Prosthe- } \\
\text { sis than for conventional prosthesis. }\end{array}$ & B \\
\hline $\begin{array}{l}\text { Isakov } \\
\text { et al. [46] }\end{array}$ & $\begin{array}{l}\text { Prosthesis with an open-knee } \\
\text { mechanism versus a locked-knee } \\
\text { mechanism }\end{array}$ & $\begin{array}{l}\text { Locked-knee mechanism enabled a higher walking speed with a lower heart rate } \\
\text { increase than open-knee. }\end{array}$ & B \\
\hline $\begin{array}{l}\text { Murray } \\
\text { et al. [61] }\end{array}$ & $\begin{array}{l}\text { Hydraulic knee (HK) } \\
\text { and constant friction } \\
\text { knee component (CFC) }\end{array}$ & $\begin{array}{l}\text { At slow speed: no differences in velocity, cadence, or stride length. Free-speed and fast } \\
\text { walking: increase in cadence and walking speed with HK. More asymmetry in stance } \\
\text { phases and swing phases with CFC. }\end{array}$ & B \\
\hline \multicolumn{4}{|l|}{ Socket } \\
\hline $\begin{array}{l}\text { Board } \\
\text { et al. [15] }\end{array}$ & $\begin{array}{l}30 \text { min walk under vacuum } \\
\text { condition and normal condition }\end{array}$ & $\begin{array}{l}\text { With vacuum stump, volume increased } 3.7 \% \text { and in normal condition, volume decreased } \\
6.5 \% \text {. Both step length and stance durations were more symmetrical with vacuum. }\end{array}$ & $\mathrm{C}$ \\
\hline \multicolumn{4}{|l|}{ Mass } \\
\hline $\begin{array}{l}\text { Czerniecki } \\
\text { et al. [27] }\end{array}$ & $\begin{array}{l}\text { Three load conditions: } 0 \mathrm{~kg} \text {, } \\
0.68 \mathrm{~kg}, 1.34 \mathrm{~kg} \text { of extra mass }\end{array}$ & No differences in self-selected walking speeds and metabolic cost. & B \\
\hline $\begin{array}{l}\text { Gailey } \\
\text { et al. [35] }\end{array}$ & $\begin{array}{l}\text { Three load conditions: } 0 \text { g, } \\
454 \text { g, } 907 \text { g of extra mass }\end{array}$ & No differences in metabolic cost. & $\mathrm{C}$ \\
\hline $\begin{array}{l}\text { Gitter } \\
\text { et al. [37] }\end{array}$ & $\begin{array}{l}\text { Three load conditions: } 0 \mathrm{~kg} \text {, } \\
0.68 \mathrm{~kg}, 1.34 \mathrm{~kg} \text { of extra mass }\end{array}$ & $\begin{array}{l}\text { No differences in timing or duration of stance and swing phase, but there was a com- } \\
\text { bined increase in hip flexor muscle contraction work and mechanical energy transfer } \\
\text { across hip joint. }\end{array}$ & B \\
\hline Hale [39] & $\begin{array}{l}\text { Three load conditions: } 0 \% \text {, } \\
75 \%, 100 \% \text { of subject's sound } \\
\text { shank mass }(1.33-3.37 \mathrm{~kg})\end{array}$ & $\begin{array}{l}\text { No differences in walking speed, stride length, stride time, and swing time. Increase in } \\
\text { prosthetic mass: decreased knee flexion and prolonged knee extension. }\end{array}$ & $\mathrm{C}$ \\
\hline $\begin{array}{l}\text { Lehmann } \\
\text { et al. [54] }\end{array}$ & $\begin{array}{l}\text { Proximal center of mass location } \\
\text { versus distal center of mass } \\
\text { location, prosthesis weights of } \\
42 \% \text { to } 70 \% \text { of normal-limb weight }\end{array}$ & $\begin{array}{l}\text { Proximal center of mass location produced a more efficient gait. Weight change from } \\
42 \% \text { to } 70 \% \text { of normal had no significant effect. }\end{array}$ & $\mathrm{C}$ \\
\hline $\begin{array}{l}\text { Mattes } \\
\text { et al. [59] }\end{array}$ & $\begin{array}{l}\text { Three load conditions: } 0 \% \text {, } \\
50 \%, 100 \% \text { of subject's sound } \\
\text { shank mass }(0.85-1.70 \mathrm{~kg})\end{array}$ & $\begin{array}{l}\text { No differences in step length and symmetry in step length. Prosthetic limb swing time } \\
\text { increased as its mass and moment of inertia were increased, whereas that for intact limb } \\
\text { was relatively unaffected by inertial manipulation of prosthetic limb. Energy cost of } \\
\text { walking increased significantly as inertial properties of prosthetic limb and intact limbs } \\
\text { became more similar because of prosthetic limb loading. }\end{array}$ & $\mathrm{C}$ \\
\hline
\end{tabular}

be related to the mechanical characteristics of the different feet, i.e., the presence or absence of an ankle axis in the frontal plane. The presence of an ankle axis allowed greater early-stance plantar flexion immediately after heel contact $[66,67]$. Furthermore, the energy-storing Flex-Foot showed a greater late-stance dorsiflexion compared with the conventional SACH foot in three B-level studies $[69,77,81]$ and two C-level studies $[52,76]$ on traumatic and vascular transtibial amputees. The fact that the Flex-Foot resulted in a greater stride length indicates a greater tibial advancement as a result of increased dorsiflexion [77].

Nine B-level studies assessed oxygen consumption $[13,20,44,45,52,58,76,81,83]$. In three studies with traumatic transtibial amputees, oxygen consumption per distance traveled was slightly lower with a prototype 
energy-storing foot [20] or with the Flex-Foot $[58,63]$ than with the SACH foot. In the study of Hsu et al. with nonvascular amputees, oxygen consumption was lower with the Re-Flex VSP compared with the SACH and Flex-Foot [44]. However, in the other six studies no such beneficial effect of energy-storing feet was found $[13,45,52,76,81,83]$. This discrepancy in results, however, is hardly clinically significant and may again be related to differences in the selection of the study groups.

As for patient satisfaction, the only A-level study concluded that no specific prosthetic foot was consistently favored over another type of foot by traumatic transtibial amputees [68]. Yet, in one B-level study, the prototype energy-storing foot scored a higher satisfaction rate than the SACH foot in traumatic transtibial amputees [20]. Another B-level study concluded that walking with the SACH foot was perceived to be more difficult than walking with the Flex-Foot [56]. However, since the prosthetic users were not blinded in the latter two studies, these results should be interpreted with caution.

\section{Studies on Prosthetic Knees}

Each of the five studies on prosthetic knees made different comparisons (Table 4). The A-level study of Boonstra et al. concluded that a Tehlin knee with a pneumatical swing phase controller resulted in a more comfortable and faster walking performance during normal and fast walking compared to a knee with a mechanical swing phase control, i.e., Otto Bock 3R20 (results from questionnaires) [18]. This result was explained by a shorter swing phase duration of the prosthetic leg caused by an impeded knee flexion. However, energy expenditure at $3 \mathrm{~km} / \mathrm{h}$ was somewhat higher with the pneumatically controlled knee [17]. Apparently, the preference of the amputees in favor of the Tehlin knee was not related to lower energy costs. Similar results were found in two B-level studies. Heller et al. found that a conventional knee unit resulted in greater total frontal plane excursion of the head compared to the Intelligent Prosthetic knee (a microprocessorcontrolled prosthesis) [42], whereas Murray et al. found more symmetry in both stance- and swing-phase duration and a higher comfortable and fast walking speed for a prosthesis with a hydraulic knee compared to a prosthesis with a constant-friction knee in traumatic transfemoral amputees [61]. Apparently, these results indicate that a more advanced mode of control of the prosthetic knee movement during the swing phase can lead to more gait symmetry and speed than simply applying constant fric- tion or force to the knee, particular in active prosthetic users. The improvements in the smoothness of walking are most likely related to the restraining effect of the hydraulic or pneumatic component at the beginning and the end of the prosthetic swing phase, allowing more normal weight acceptance at the beginning of the prosthetic stance phase and easier weight transfer at the end of prosthetic stance phase [61]. On the other hand, the B-level study of Isakov et al. [46] concluded that a Mauch S-N-S hydraulic knee prosthesis with a locked knee may enable vascular patients to adopt a higher walking speed compared to an unlocked open-knee unit. This finding should be interpreted in view of the fact that their study sample was characterized by an older age (50-70 years) and a lower activity level (i.e., vascular amputees with additional health problems, such as diabetes mellitus, hypertension, heart failure, and myocardial infarction) compared to the studies of Boonstra et al. $[17,18]$ and Heller et al. [42].

\section{Study on Prosthetic Socket}

Board et al.'s C-level study investigated the effect of prosthetic socket type on time-distance parameters in transtibial amputees [15] (Table 4). More symmetrical step length and stance duration and less stump volume loss were observed with a vacuum total surface-bearing suction socket compared to a normal total surface-bearing suction socket. This result can be explained by the assumption that a vacuum socket provides a better fitting of the stump tissues and a better "total skin" contact, allowing more mechanical and sensory control over the prosthetic leg. The subjects reported that their prosthetic limb was held more firmly with the vacuum socket and that their stump pistoned less within the socket during walking. Because of the better fit, the amputees spent more time on their prosthetic limb and felt more confident of the control over and position of their prosthesis. The methodological quality of this study was poor, however, because the other prosthetic components were not kept constant with the different sockets. Also the time to adapt to the prosthetic change was relatively short, i.e., subjects were familiarized with the intervention for only 15 minutes. Therefore, the results of this study should be interpreted with caution.

\section{Studies on Prosthetic Mass}

The six studies on prosthetic mass (Table 4) did not reveal any influence of mass on the efficiency or 
kinematics of gait, with one exception. Lehmann's Clevel study showed that a more proximal center of mass location produced a more efficient gait in traumatic transtibial amputees [54]. Although Selles et al. reviewed a slightly different selection of studies on this specific topic, their conclusion is more or less the same [89]. More specifically, they concluded that inertial loading of the modern lightweight lower-limb prosthesis has no beneficial effect on the amputee's gait pattern or energy expenditure.

\section{DISCUSSION}

Limited unbiased information can currently be obtained from studies on the effects of different prosthetic components on human functioning with a lowerlimb prosthesis for evidence-based prosthetic prescription. Only four A-level studies were identified, two on prosthetic feet and two on prosthetic knees.

Some evidence suggests that energy-storing feet such as the Flex-Foot result in a comfortable walking speed and stride length that are about 7 to 13 percent higher than with a conventional SACH foot in both traumatic and vascular transtibial amputees [20,69,77]. This difference is probably related to an amputee's having slightly lower oxygen consumption while walking with an energy-storing foot $[20,58]$. Possibly, such feet also facilitate the symmetry of gait [57]. These considerations seem important, particularly for the active prosthetic user. On the other hand, prosthetic feet with an ankle axis in the frontal plane, such as the single-axis Lager foot (Otto Bock), mimic the normal roll-off motion of the ankle-foot complex in the sagittal plane, allowing an early foot-flat position and concomitant early-stance-phase stability. Some researchers believe that especially the more inactive prosthetic users may benefit from an early foot-flat mechanism to facilitate weight transfer onto their prosthesis $[1,66,67]$. According to Perry et al., the stability of timely foot-flat support with limited knee flexion requires a greater arc of functionally restrained plantar flexion [66]. Also, uphill and downhill walking may be easier with a wide ROM at the prosthetic ankle joint [58]. A single-axis foot, however, may offer relatively little late-stance stability because of an unrestrained dorsiflexion [66]. In this respect, the Flex-Foot and the SACH foot provide more stability during the latestance phase [45] and may be preferable to patients who tend toward a short prosthetic stance phase. Hence, indivi- dual considerations related to intended use and activity level remain important with respect to the definitive choice of the prosthetic foot. One should note that in the reviewed studies, dorsiflexion is also used for the prosthetic feet that have rigid ankles. This can be confusing because they do not truly dorsiflex, but bend. Therefore, pseudo-dorsiflexion could be more appropriate when one is discussing the properties of rigid ankles.

As for the prosthetic knee in transfemoral amputees, one can conclude that a prosthesis with an advanced mode of swing-phase control, either by a pneumatic or a hydraulic knee unit, is somewhat superior to a prosthetic knee that only provides a constant force or friction. Especially active prosthetic users may profit from the advanced characteristics of swing-phase controllers, such as the Tehlin knee, in terms of gait symmetry and comfortable walking speed [42,61]. These beneficial effects cannot readily be explained on the basis of energy expenditure. On the other hand, the typical geriatric vascular patient may still profit from the stance-phase stability that is provided by a conventional locked-knee unit [46]. To what extent prosthetic knees with stance-phase stabilizers such as the Intelligent Prosthetic Knee should be prescribed to these or other patients based on its functional benefits has to be further supported by clinical evidence. Hence, again, individual considerations must ultimately determine the choice and prescription of the prosthetic knee.

With regard to the prosthetic socket used by transtibial amputees, firm conclusions cannot be drawn from the literature. It is, nevertheless, plausible from a clinical perspective that a vacuum (total-surface bearing) socket assures a better skin contact than a normal suction or suspension socket and, thus, a better control over the prosthetic limb [14]. Within certain limits, prosthetic mass does not seem to influence the gait pattern or efficiency in lower-limb amputees. However, there is some evidence that a proximal center of mass location results in a slightly more efficient gait than a distal distribution of prosthetic mass [54].

Functional outcomes should be assessed for various aspects of mobility, such as making transfers, maintaining balance, walking level, climbing stairs, negotiating ramps and obstacles, changing walking speed, etc. Most studies reviewed in this paper assessed walking on a treadmill (at self-selected walking speeds), probably for reasons of technical and practical convenience. Indeed, Mulder et al. already pointed out that the vast majority of clinical studies 
on human walking have used rather standardized gait assessment protocols with limited "ecological validity" [90]. Although perhaps less analytic, modern systems for ambulatory monitoring of human activity [91] can provide objective and valid data about (changes in) human motor behavior during prolonged periods of hours or days in a much more ecologically valid way. First, subjective assessments of comfort, stability, and efficiency should certainly be used more when blinding of the prosthetic users can be assured. Second, the effects of different prosthetic feet should also be evaluated in patients with, for example, a through-knee or transfemoral amputation because generalizing results from transtibial amputees to these higher levels of amputation may be invalid. Last, more research is needed into the effects of prosthetic knees with stancephase stabilizers as well as into the functional effects of different prosthetic sockets in through-knee and transfemoral amputees.

Therefore, with regard to prosthetic guideline development, we must still largely rely on clinical consensus among experts. In a formal consensus procedure, different sources of evidence are needed.

\section{CONCLUSION}

Our formal clinical knowledge has considerable gaps concerning the (beneficial) effects of different prosthetic components on human functioning with a lower-limb prosthesis. For future research, functional comparisons between different prosthetic components should be categorized according to the level of activity of the amputee and the intended use of the prosthesis. Such an approach would better acknowledge the importance of individual needs and abilities that guide clinical decision-making in daily practice. The integration of knowledge from research with the expert opinion of clinical professionals and the opinions and wishes of consumers can form a solid base for a procedure on guideline development for prosthetic prescription.

\section{REFERENCES}

1. Goh JC, Solomonidis SE, Spence WD, Paul JP. Biomechanical evaluation of SACH and uniaxial feet. Prosthet Orthot Int. 1984;8(3):147-54.
2. Menard MR, McBride ME, Sanderson DJ, Murray DD. Comparative biomechanical analysis of energy-storing prosthetic feet. Arch Phys Med Rehabil. 1992;73(5):451-58.

3. Cortes A, Viosca E, Hoyos JV, Prat J, Sanchez-Lacuesta J. Optimisation of the prescription for trans-tibial (TT) amputees. Prosthet Orthot Int. 1997;21(3):168-74.

4. Woolf SH, Grol R, Hutchinson A, Eccles M, Grimshaw J. Potential benefits, limitations, and harms of clinical guidelines. BMJ. 1999;318:527-30.

5. van Tulder MW, Assendelft WJ, Koes BW, Bouter LM. Method guidelines for systematic reviews in the Cochrane collaboration back review group for spinal disorders. Spine. 1997;22(20):2323-30.

6. Verhagen AP, de Vet HC, de Bie RA, Kessels AG, Boers M, Bouter LM, et al. The Delphi list: a criteria list for quality assessment of randomized clinical trials for conducting systematic reviews developed by Delphi consensus. J Clin Epidemiol. 1998;51(12):1235-41.

7. Piantadosi S. Clinical trials as experimental designs. In: Barnett V, Bardley RA, Fisher NI, Hunter S, Kadane JB, Kendall DG, et al., editors. Clinical trial: a methodological perspective. New York, Chichester, Weinheim, Brisbane, Singapore, Toronto: John Wiley \& Sons, Inc; 1997. p. 61-105.

8. English RD, Hubbard WA, McElroy GK. Establishment of consistent gait after fitting of new components. J Rehabil Res Dev. 1995;2(1):32-35.

9. Moher D, Cook DJ, Eastwood S, Olkin I, Rennie D, Stroup DF. Improving the quality of reports of meta-analyses of randomised controlled trials: the QUOROM statement. Quality of reporting of meta-analyses. Lancet. 1999;354(9193): 1896-900.

10. Alaranta H, Kinnunen A, Karkkainen M, Pohjalainen T, Heliovaara M. Practical benefits of Flex-Foot in belowknee amputees. J Prosthet Orthot. 1991;3:179-81.

11. Alaranta H, Lempinen VM, Haavisto E, Pohjolainen T, Hurri H. Subjective benefits of energy storing prostheses. Prosthet Orthot Int. 1994;18(2):92-97.

12. Arya AP, Lees A, Nirula HC, Klenerman L. A biomechanical comparison of the SACH, Seattle and Jaipur feet using ground reaction forces. Prosthet Orthot Int. 1995;19(1):37-45.

13. Barth DG, Schumacher L, Thomas SS. Gait analysis and energy cost of below-knee amputees wearing six different prosthetic feet. J Prosthet Orthot. 1992;4:63-75.

14. Blumentritt S, Schmalz T, Jarasch R. Influence of static prosthetic alignment on standing posture and walking in transtibial amputees. Orthopade. 2001;30(3):161-68.

15. Board WJ, Street GM, Caspers C. A comparison of transtibial amputee suction and vacuum socket conditions. Prosthet Orthot Int. 2001;25(3):202-9.

16. Boonstra AM, Fidler V, Spits GM, Tuil P, Hof AL. Comparison of gait using a Multiflex foot versus a Quantum 
foot in knee disarticulation amputees. Prosthet Orthot Int. 1993;17(2):90-94.

17. Boonstra AM, Schrama JM, Fidler V, Eisma WH. Energy cost during ambulation in transfemoral amputees: a knee joint with a mechanical swing phase control vs. a knee joint with a pneumatic swing phase control. Scand J Rehabil Med. 1995;27(2):77-81.

18. Boonstra AM, Schrama JM, Eisma WH, Hof AL, Fidler V. Gait analysis of transfemoral amputee patients using prostheses with two different knee joints. Arch Phys Med Rehabil. 1996;77(5):515-20.

19. Buckley JG, Spence WD, Solomonidis SE. Energy cost of walking: comparison of "intelligent prosthesis" with conventional mechanism. Arch Phys Med Rehabil. 1997;78(3): 330-33.

20. Casillas JM, Dulieu V, Cohen M, Marcer I, Didier JP. Bioenergetic comparison of a new energy-storing foot and SACH foot in traumatic below-knee vascular amputations. Arch Phys Med Rehabil. 1995;76(1):39-44.

21. Chino N, Pearson JR, Cockrell JL, Mikishko HA, Koepke $\mathrm{GH}$. Negative pressures during swing phase in below-knee prostheses with rubber sleeve suspension. Arch Phys Med Rehabil. 1975;56(1):22-26.

22. Culham EG, Peat M, Newell E. Analysis of gait following below-knee amputation: a comparison of the SACH and single-axis foot. Physiother Can. 1984;36(5):237-42.

23. Culham EG, Peat M, Newell E. Below-knee amputation: a comparison of the effect of the SACH foot and single-axis foot on electromyographic patterns during locomotion. Prosthet Orthot Int. 1986;10(1):15-22.

24. Cummings V, March H, Steve L, Robinson KG. Energy costs of below-knee prostheses using two types of suspension. Arch Phys Med Rehabil. 1979;60(7):293-97.

25. Czerniecki JM, Gitter A, Munro C. Joint moment and muscle power output characteristics of below knee amputees during running: the influence of energy storing prosthetic feet. J Biomech. 1991;24(1):63-75.

26. Czerniecki J, Gitter A. Insights into amputee running: a muscle work analysis. Am J Phys Med Rehabil. 1992; 71(4):209-18.

27. Czerniecki JM, Gitter A, Weaver K. Effect of alterations in prosthetic shank mass on the metabolic costs of ambulation in above-knee amputees. Am J Phys Med Rehabil. 1994; 73(5):348-52.

28. Czerniecki J, Gitter A, Beck JC. Energy transfer mechanisms as a compensatory strategy in below knee amputee runners. J Biomech. 1996;29(6):717-22.

29. Dasgupta AK, McCluskie PJ, Patel VS, Robins L. The performance of the ICEROSS prostheses amongst transtibial amputees with a special reference to the workplace: a preliminary study. Icelandic roll on silicone socket. Occup Med (Lond). 1997;47(4):228-36.
30. Doane NE, Holt LE. A comparison of the SACH and singleaxis foot in the gait of unilateral below-knee amputees. Prosthet Orthot Int. 1983;7(1):33-36.

31. Donn JM, Porter D, Roberts VC. The effect of footwear mass on the gait patterns of unilateral below-knee amputees. Prosthet Orthot Int. 1989;13(3):140-44.

32. Ellepola W, Sheredos SJ. Report on the evaluation of the VA/Seattle below-knee prosthesis. J Rehabil Res Dev. 1993;30(2):260-66.

33. Gailey RS, Lawrence D, Burditt C, Spyropoulos P, Newell C, Nash MS. The CAT-CAM socket and quadrilateral socket: a comparison of energy cost during ambulation. Prosthet Orthot Int. 1993;17(2):95-100.

34. Gailey RS, Wenger MA, Raya M, Kirk N, Erbs K, Spyropoulos $\mathrm{P}$, et al. Energy expenditure of trans-tibial amputees during ambulation at self-selected pace. Prosthet Orthot Int. 1994;18(2):84-91.

35. Gailey RS, Nash MS, Atchley TA, Zilmer RM, Moline-Little GR, Morris-Cresswell N, et al. The effects of prosthesis mass on metabolic cost of ambulation in non-vascular trans-tibial amputees. Prosthet Orthot Int. 1997;21(1):9-16.

36. Gitter A, Czerniecki JM, DeGroot DM. Biomechanical analysis of the influence of prosthetic feet on below-knee amputee walking. Am J Phys Med Rehabil. 1991;70(3): 142-48.

37. Gitter A, Czerniecki J, Meinders M. Effect of prosthetic mass on swing phase work during above-knee amputee ambulation. Am J Phys Med Rehabil. 1997;76(2):114-21.

38. Godfrey CM, Brett R, Jousse AT. Foot mass effect on gait in the prosthetic limb. Arch Phys Med Rehabil. 1977;58(6): 268-69.

39. Hale SA. Analysis of the swing phase dynamics and muscular effort of the above-knee amputee for varying prosthetic shank loads. Prosthet Orthot Int. 1990;14(3):125-35.

40. Hannah RE, Orrison JB, Hapman AE. Prostheses alignment: effect on gait of persons with below-knee amputations. Arch Phys Med Rehabil. 1984;65(4):159-62.

41. Hatfield AG, Morrison JD. Polyurethane gel liner usage in the Oxford Prosthetic Service. Prosthet Orthot Int. 2001; 25(1):41-46.

42. Heller BW, Datta D, Howitt J. A pilot study comparing the cognitive demand of walking for transfemoral amputees using the Intelligent Prosthesis with that using conventionally damped knees. Clin Rehabil. 2000;14(5):518-22.

43. Hill-Watson S, Sheredos SJ. Report on the evaluation of the DAV/Seattle Knee. J Rehabil Res Dev. 1994;31(1):62-69.

44. Hsu MJ, Nielsen DH, Yack HJ, Shurr DG. Physiological measurements of walking and running in people with transtibial amputations with 3 different prostheses. J Orthop Sports Phys Ther. 1999;29(9):526-33. 
45. Huang GF, Chou YL, Su FC. Gait analysis and energy consumption of below-knee amputees wearing three different prosthetic feet. Gait Posture. 2000;12(2):162-68.

46. Isakov E, Susak Z, Becker E. Energy expenditure and cardiac response in above-knee amputees while using prostheses with open and locked knee mechanisms. Scand J Rehabil Med Suppl. 1985;12:108-11.

47. Isobe Y, Takeuchi T, Furuya K, Hosoda K. A Japanese lower limb prosthesis with a fore-joint foot and turntable. Int Orthop. 1982;6(1):49-54.

48. van Jaarsveld HW, Grootenboer HJ, de Vries J. Accelerations due to impact at heel strike using below-knee prosthesis. Prosthet Orthot Int. 1990;14(2):63-66.

49. James KB, Stein RB. Improved ankle-foot system for above-knee amputees. Am J Phys Med Rehabil. 1986; 65(6):301-14.

50. Jergesen HE, Hoaglund FT, Roberts RA, Wilson LA, Lamoreux LW, Radcliffe CW. The University of California Biomechanics Laboratory four-bar polycentric knee linkage. A clinical trial in 20 active above-knee amputees. Clin Orthop. 1986;204:184-92.

51. Kohler P, Lindh L, Netz P. Comparison of CAD-CAM and hand-made sockets for PTB prostheses. Prosthet Orthot Int. 1989;13(1):19-24.

52. Lehmann JF, Price R, Boswell-Bessette S, Dralle A, Questad K. Comprehensive analysis of dynamic elastic response feet: Seattle Ankle/Lite Foot versus SACH foot. Arch Phys Med Rehabil. 1993;74(8):853-61.

53. Lehmann JF, Price R, Boswell-Bessette S, Dralle A, Questad K, de Lateur BJ. Comprehensive analysis of energy storing prosthetic feet: Flex-Foot and Seattle Foot versus standard SACH foot. Arch Phys Med Rehabil. 1993; 74(11):1225-31.

54. Lehmann JF, Price R, Okumura R, Questad K, de Lateur BJ, Negretot A. Mass and mass distribution of below-knee prostheses: effect on gait efficacy and self-selected walking speed. Arch Phys Med Rehabil. 1998;79(2):162-68.

55. MacFarlane PA, Nielsen DH, Shurr DG, Meier K. Gait comparisons for below-knee amputees using a Flex-Foot versus a conventional prosthetic foot. J Prosthet Orthot. 1991;3(4):150-61.

56. MacFarlane PA, Nielsen DH, Shurr DG, Meier K. Perception of walking difficulty by below-knee amputees using a conventional foot versus the Flex-Foot. J Prosthet Orthot. 1991;3(31):114-19.

57. MacFarlane PA, Nielsen DH, Shurr DG, Meier K, Clark R, Kerns J, et al. Transfemoral amputee physiological requirements: comparisons between SACH foot walking and FlexFoot walking. J Prosthet Orthot. 1997;9:138-43.

58. MacFarlane PA, Nielsen DH, Shurr DG. Mechanical gait analysis of transfemoral amputees: SACH foot versus the Flex-Foot. J Prosthet Orthot. 1997;9(4):144-51.
59. Mattes SJ, Martin PE, Royer TD. Walking symmetry and energy cost in persons with unilateral transtibial amputations: matching prosthetic and intact limb inertial properties. Arch Phys Med Rehabil. 2000;81(5):561-68.

60. Mizuno N, Aoyama T, Nakajima A, Kasahara T, Takami K. Functional evaluation by gait analysis of various ankle-foot assemblies used by below-knee amputees. Prosthet Orthot Int. 1992;16(3):174-82.

61. Murray MP, Mollinger LA, Sepic SB, Gardner GM, Linder MT. Gait patterns in above-knee amputee patients: hydraulic swing control vs. constant-friction knee components. Arch Phys Med Rehabil. 1983;64(8):339-45.

62. Narita H, Yokogushi K, Shii S, Kakizawa M, Nosaka T. Suspension effect and dynamic evaluation of the total surface bearing (TSB) trans-tibial prosthesis: a comparison with the patellar tendon bearing (PTB) trans-tibial prosthesis. Prosthet Orthot Int. 1997;21(3):175-78.

63. Nielsen DH, Shurr DG, Golden JC, Meier K. Comparison of energy cost and gait efficiency during ambulation in below-knee amputees using different prosthetic feet. J Prosthet Orthot. 1988;1:24-31.

64. Oberg T, Lilja M, Johansson T, Karsznia A. Clinical evaluation of trans-tibial prosthesis sockets: a comparison between CAD CAM and conventionally produced sockets. Prosthet Orthot Int. 1993;17(3):164-71.

65. Otter N, Postema K, Rijken RA, van Limbeek J. An open socket technique for through-knee amputations in relation to skin problems of the stump: an explorative study. Clin Rehabil. 1999;13(1):34-43.

66. Perry J, Boyd LA, Rao SS, Mulroy SJ. Prosthetic weight acceptance mechanics in transtibial amputees wearing the Single Axis, Seattle Lite, and Flex-Foot. IEEE Trans Rehabil Eng. 1997;5(4):283-89.

67. Postema K, Hermens HJ, de Vries J, Koopman HF, Eisma WH. Energy storage and release of prosthetic feet. Part 1: Biomechanical analysis related to user benefits. Prosthet Orthot Int. 1997;21(1):17-27.

68. Postema K, Hermens HJ, de Vries J, Koopman HF, Eisma WH. Energy storage and release of prosthetic feet. Part 2: Subjective ratings of 2 energy-storing and 2 conventional feet, user choice of foot and deciding factor. Prosthet Orthot Int. 1997;21(1):28-34.

69. Powers CM, Torburn L, Perry J, Ayyappa E. Influence of prosthetic foot design on sound limb loading in adults with unilateral below-knee amputations. Arch Phys Med Rehabil. 1994;75(7):825-29.

70. Prince F, Winter DA, Sjonnensen G, Powell C, Wheeldon RK. Mechanical efficiency during gait of adults with transtibial amputation: a pilot study comparing the SACH, Seattle, and Golden-Ankle prosthetic feet. J Rehabil Res Dev. 1998;35(2):177-85. 
71. Rao SS, Boyd LA, Mulroy SJ, Bontrager EL, Gronley JK, Perry J. Segment velocities in normal and transtibial amputees: prosthetic design implications. IEEE Trans Rehabil Eng. 1998;6(2):219-26.

72. Roberts RA. Suction socket suspension for below-knee amputees. Arch Phys Med Rehabil. 1986;67(3):196-99.

73. Sanders JE, Bell DM, Okumura RM, Dralle AJ. Effects of alignment changes on stance phase pressures and shear stresses on transtibial amputees: measurements from 13 transducer sites. IEEE Trans Rehabil Eng. 1998;6(1):21-31.

74. Sanders JE, Daly CH. Interface pressures and shear stresses: sagittal plane angular alignment effects in three trans-tibial amputee case studies. Prosthet Orthot Int. 1999; 23(1):21-29.

75. Sanders JE, Zachariah SG, Baker AB, Greve JM, Clinton C. Effects of changes in cadence, prosthetic componentry, and time on interface pressures and shear stresses of three trans-tibial amputees. Clin Biomech (Bristol, Avon). 2000; 15(9):684-94.

76. Schmalz T, Blumentritt S, Jarasch R. Energy expenditure and biomechanical characteristics of lower limb amputee gait: the influence of prosthetic alignment and different prosthetic components. Gait Posture. 2002;16(3):255-63.

77. Snyder RD, Powers CM, Fontaine C, Perry J. The effect of five prosthetic feet on the gait and loading of the sound limb in dysvascular below-knee amputees. J Rehabil Res Dev. 1995;32(4):309-15.

78. Sonck WA, Cockrell JL, Koepke GH. Effect of liner materials on interface pressure in below-knee amputees. Arch Phys Med Rehabil. 1970;51(11):666-69.

79. Stein JL, Flowers WC. Stance phase control of above-knee prostheses: knee control versus SACH foot design. J Biomech. 1987;20(1):19-28.

80. Stinus H. Biomechanics and evaluation of the microprocessorcontrolled C-Leg exoprosthesis knee joint. Z Orthop Ihre Grenzgeb. 2000;138(3):278-82.

81. Torburn L, Perry J, Ayyappa E, Shanfield SL. Below-knee amputee gait with dynamic elastic response prosthetic feet: a pilot study. J Rehabil Res Dev. 1990;27(4):369-84.
82. Torburn L, Schweiger GP, Perry J, Powers CM. Belowknee amputee gait in stair ambulation. A comparison of stride characteristics using five different prosthetic feet. Clin Orthop. 1994;(303):185-92.

83. Torburn L, Powers CM, Guiterrez R, Perry J. Energy expenditure during ambulation in dysvascular and traumatic below-knee amputees: a comparison of five prosthetic feet. J Rehabil Res Dev. 1995;32(2):111-19.

84. Traugh GH, Corcoran PJ, Reyes RL. Energy expenditure of ambulation in patients with above-knee amputations. Arch Phys Med Rehabil. 1975;56(2):67-71.

85. Wirta RW, Golbranson FL, Mason R, Calvo K. Analysis of below-knee suspension systems: effect on gait. J Rehabil Res Dev. 1990;27(4):385-96.

86. Wirta RW, Mason R, Calvo K, Golbranson FL. Effect on gait using various prosthetic ankle-foot devices. J Rehabil Res Dev. 1991;28(2):13-24.

87. Yang L, Solomonidis SE, Spence WD, Paul JP. The influence of limb alignment on the gait of above-knee amputees. J Biomech. 1991;24(11):981-97.

88. Cochran G. A primer of orthopaedic biomechanics. 1st ed. New York: Churchill Livingstone Inc.; 1982.

89. Selles RW, Bussmann JB, Wagenaar RC, Stam HJ. Effects of prosthetic mass and mass distribution on kinematics and energetics of prosthetic gait: a systematic review. Arch Phys Med Rehabil. 1999;80(12):1593-99.

90. Mulder T, Nienhuis B, Pauwels J. Clinical gait analysis in a rehabilitation context: some controversial issues. Clin Rehabil. 1998;12(2):99-106.

91. Bussmann JB, Martens WL, Tulen JH, Schasfoort FC, van den Berg-Emons HJ, Stam HJ. Measuring daily behavior using ambulatory accelerometry: the Activity Monitor. Behav Res Methods Instrum Comput. 2001;33(3):349-56.

Submitted for publication June 26, 2003. Accepted in revised form July 25, 2003. 
Appendix: Methodological Criteria

Selection of Patients

A1, Adequacy of Description of Inclusion and Exclusion Criteria: This criterion tested whether the patient sample was sufficiently defined with the use selection criteria: such as age, gender, level of amputation, reason for amputation, activity level of the amputee, time since onset, stump condition, and comorbidity.

A2, Functional Homogeneity: The homogeneity of the study sample was assessed for all study designs. In view of clinical guideline development, at least the activity level of the included subjects should be reasonably equal. When the activity level of the patients was not described, sufficient indication of the level of amputation, the reason for amputation, and the age of the subjects were required to globally estimate the activity level of the patients. If the study sample was heterogeneous, a stratified analysis of the outcome was required to obtain a "1" score. A3, Prognostic Comparability: As for group designs, the study groups should be comparable for possible confounding factors, such as time since onset and time since first walking with the prosthesis. In the case of a within-subjects design, this criterion was scored “1.”

A4, Randomization: In group designs, an adequate randomization procedure should have been applied. If the randomization procedure was described and the procedure reasonably excluded bias, this criterion was scored as “1.” In within-subjects designs, this criterion was applied to the sequence of interventions [1]. Intervention and Assessment

B5, Experimental Intervention: The experimental intervention had to be given explicitly in such detail as to make performing a duplicate study as described possible.

B6, Cointerventions: This criterion tested whether cointerventions were avoided or were comparable between the study groups.

B7, Blinding: In any case, the outcome assessor had to be blinded to the intervention. In many studies investigating prosthetic components, blinding of the patients is always difficult to assure. Therefore, this type of blinding was required only for studies using subjective outcome measures.

B8, Timing of the Measurement: This criterion pertained to the moment that the outcome was assessed in relation to the time period subjects were given to adapt to the prosthetic change. An adequate adaptation period was required. According to English et al., transfemoral amputees need at least 3 weeks of walking with a new knee 
mechanism to be sure that gait parameters are stable [2]. Also according to English's results and based on clinical experience [2], the amputees are assumed to need a period of at least 1 week to adapt to a new prosthetic foot or to a change in prosthetic mass.

B9, Outcome Measures: The outcome parameters should be adequate in relation to the purpose of the study, and they should have been collected with the use of a standardized protocol.

Statistical validity:

C10, Dropouts: The number of dropouts and the reason for dropping out had to be sufficiently reported. A dropout rate of more than $20 \%$ was considered as insufficient.

C11, Sample Size: The sample size $(n)$ in relation to the number of independent variables $(K)$ was adequate if the ratio $n: K$ exceeded 10:1.

C12, Intention to Treat: Intention to treat analysis should be assessed in the case of dropouts.

C13, Data Presentation: This criterion required that adequate point estimates and measures of variability were presented for the primary outcome measures.

1. Piantadosi S. Clinical trials as experimental designs. In: Barnett V, Bardley RA, Fisher NI, Hunter S, Kadane JB, Kendall DG, et al., editors. Clinical trial: a methodological perspective. New York, Chichester, Weinheim, Brisbane, Singapore, Toronto: John Wiley \& Sons, Inc; 1997. p. 61-105.

2. English RD, Hubbard WA, McElroy GK. Establishment of consistent gait after fitting of new components. J Rehabil Res Dev. 1995;2(1):32-35. 